\title{
Tropical Atlantic convection as revealed by ozone and relative humidity measurements
}

\author{
Dieter Kley, ${ }^{1,2}$ Herman G. J. Smit, ${ }^{3}$ Susanne Nawrath, ${ }^{4}$ Zhengzhao Luo, ${ }^{1}$ \\ Philippe Nedelec, ${ }^{5}$ and Richard H. Johnson ${ }^{1}$ \\ Received 1 March 2007; revised 15 May 2007; accepted 10 August 2007; published 14 December 2007.
}

[1] Properties of deep convection over the tropical central Atlantic are analyzed in light of ozone as a quasi-conservative quantity on the convective timescale. Multiple years of measurements of ozone from aircraft, shipboard and balloon platforms reveal that the mean ozone mixing ratio near $250 \mathrm{hPa}$, close in time and distance to the convective outflow at that pressure, is $7 \mathrm{ppb}$ higher than at sea surface and marine boundary layer (MBL). The process that increases the ozone mixing ratio in the convective outflow is shown to be lateral entrainment of higher value ozone mixing ratio originating from the subsiding branch of the Hadley Cell. Ozone and humidity soundings obtained from cruise campaigns over the same region are used to identify the preferred or most pronounced levels of entrainment, which appear to be near $700 \mathrm{hPa}$ and from 500 to $400 \mathrm{hPa}$, as indicated by layers of simultaneous drying and enhanced ozone mixing ratio in otherwise smooth profiles. There are also indications of convective detrainment at around $600 \mathrm{hPa}$ and $300 \mathrm{hPa}$, which may correspond to shallow and deep convection, respectively. A simple model is used to estimate the ratio of the bulk entrainment mass flux $\left(\Phi_{2}\right)$ between 900 and $400 \mathrm{hPa}$ to the convective mass flux from the MBL below $\left(\Phi_{1}\right)$. The ratio is calculated, on the basis of climatological ozone measurements, to be $\Phi_{2} / \Phi_{1}=$ 0.50 . Thus the bulk outflow is $50 \%$ larger than the lateral mass flux in the MBL. The relative humidity over ice $(\mathrm{RHi})$ of air at the convective outflow is centered at $\mathrm{RHi}=$ $110 \%$, with a considerable range from a low near $40 \%$ to a high near $150 \%$.

Citation: Kley, D., H. G. J. Smit, S. Nawrath, Z. Luo, P. Nedelec, and R. H. Johnson (2007), Tropical Atlantic convection as revealed by ozone and relative humidity measurements, J. Geophys. Res., 112, D23109, doi:10.1029/2007JD008599.

\section{Introduction}

[2] The tropical marine boundary layer (MBL) is a region of low surface pressure. Frequent deep convection transports MBL air of high equivalent potential temperature $\left(\Theta_{\mathrm{e}}\right)$ to the middle and upper troposphere where it is subsequently exported to higher latitudes via the Hadley circulation [Riehl and Malkus, 1958]. The uplifted air is replenished by the trade winds, which supply air from north and south of the Intertropical Convergence Zone (ITCZ) to the equatorial trough zone, or by equatorward flow in monsoon troughs or equatorial disturbances. Riehl and Malkus hypothesized that undilute ascent in numerous "hot towers" in the tropics would be required to satisfy the energy balance of the equatorial trough zone. However, this idea has been recently

\footnotetext{
${ }^{1}$ Department of Atmospheric Science, Colorado State University, Fort Collins, Colorado, USA.

${ }^{2}$ Also at Institut für Chemie und Dynamik der Geosphäre: Troposphäre (ICG-II), Forschungszentrum Jülich, Jülich, Germany.

${ }^{3}$ Institut für Chemie und Dynamik der Geosphäre: Troposphäre (ICGII), Forschungszentrum Jülich, Jülich, Germany.

${ }^{4}$ Potsdam Institute for Climate Impact Research, Potsdam, Germany.

${ }^{5}$ Laboratoire d'Aérologie, CNRS UMR5560, Observatoire MidiPyrénées, Toulouse, France.
}

Copyright 2007 by the American Geophysical Union. 0148-0227/07/2007JD008599 challenged by Zipser [2003] wherein it is argued that the effects of freezing in the mid-to-upper troposphere can add sufficient buoyancy in convection so that it is not necessary to invoke undilute ascent to satisfy the energy balance requirements. Unfortunately, direct measurements of updraft cores and entrainment in tropical convection needed to solve this controversy are lacking.

[3] Tropical convection is significantly influenced by entrainment, the most prominent effects being on precipitation efficiency, height, and longevity of cloud systems. Entrainment is generally viewed in the context of cloud models, e.g., entraining plume, thermal, starting plume, buoyancy-sorting, but is normally a discontinuous process occurring in an inhomogeneous environment [Houze, 1993]. To further complicate matters, entrainment can occur both at cloud sides and cloud top. Measurements of entrainment have been difficult to obtain, intercompare, interpret, and relate to idealized cloud models and theory [Reuter, 1986]. Recent modeling studies have shown an important sensitivity of cloud development to entrainment of dry air [e.g., Redelsperger et al., 2002; Derbyshire et al., 2004; Jensen and Del Genio, 2006]. Such entrainment evidently has an important impact on cloud populations that comprise and control the evolution of tropical disturbances such as the Madden-Julian Oscillation [Mapes and Zuidema, 1996; 
Brown and Zhang, 1997; DeMott and Rutledge, 1998; Johnson et al., 1999]. The predictive skill of global models for the MJO and other tropical disturbances is quite low, and the treatment of convection, including entrainment effects, is no doubt a factor in the poor performance. Therefore measurements of the entrainment characteristics of tropical cloud systems are important for assessing deficiencies in convective parameterizations in global models.

[4] Tropospheric ozone is a quasi-conservative quantity on the convective timescale during which MBL air is rapidly transported to the upper troposphere (UT) where it is detrained, bypassing the middle troposphere. Ozone measurements obtained from instrumentation on aircraft, ships, and balloons create a unique opportunity to provide an independent measurement (independent from approaches involving moist static energy or water substance) of entrainment into tropical convection. Ozone is advected toward the ITCZ from photochemical source regions at higher latitudes, involving $\mathrm{CO}, \mathrm{CH}_{4}$, nonmethane hydrocarbons and $\mathrm{NO}_{\mathrm{x}}$ reactions. The marine boundary layer of tropical latitudes is generally characterized by low mixing ratios of $\mathrm{NO}_{\mathrm{x}}$. Below a mixing ratio of $\approx 15 \mathrm{ppt}$ ozone sinks dominate over sources [Crutzen, 1979] and, in the presence of humid air, the photochemical lifetime of ozone is reduced to a few days. As a consequence, its mixing ratio decreases equatorward as this trace gas is transported to the trough zone. Ozone mixing ratios of less than $10 \mathrm{ppb}$ have been observed in the MBL of the ITCZ [Johnson et al., 1990; Piotrowicz et al., 1991; Kley et al., 1996]. However, such low mixing ratios are infrequent. Higher mixing ratios are typically observed in the tropical MBL perhaps aided by relatively rapid transport in strong trades or by equatorial disturbances.

[5] Photochemical ozone losses involving water vapor are active in the MBL but are of minor importance in the UT because of low specific humidity. Therefore photochemical ozone generation by the oxidation of carbon compounds in the presence of $\mathrm{NO}_{\mathrm{x}}$ dominates ozone change in the UT. However, photochemical ozone change proceeds on a timescale much longer than the convective timescale. Thus locally low concentrations of ozone can be expected to be observed in the outflow regions of deep convection since ambient UT ozone concentrations are greater than those in the tropical MBL. Ozone can be used for the diagnosis of deep convection if measurements of ozone are made under the conditions of $\mathrm{O}_{3}(\mathrm{MBL})<\mathrm{O}_{3}$ (UT) when referring to the environmental mean state. Active or recent convection is diagnosed when $\mathrm{O}_{3}(\mathrm{UT}) \approx \mathrm{O}_{3}(\mathrm{MBL})$ is observed [Kley et al. 1996, 1997]. Vertical profiles of ozone over the tropical Atlantic were measured in 1987-1988 by balloons launched from the R/V Polarstern [Smit et al., 1990]. Kley et al. [1996] and Kley et al. [1997] measured ozone profiles over the tropical central Pacific Ocean. Their results have demonstrated the utility of ozone minima in the UT for the diagnosis of deep convection.

[6] The objectives of this paper are to provide and analyze a climatology of UT ozone over the tropical Atlantic in proximity to deep convection and to infer properties of entrainment and its influence on ozone and relative humidity in near-equatorial convection from a combined aircraft-shipboard data set. Measurements of ozone and humidity on commercial aircraft from late 1994 to April 2000 are used and classified according to the time it

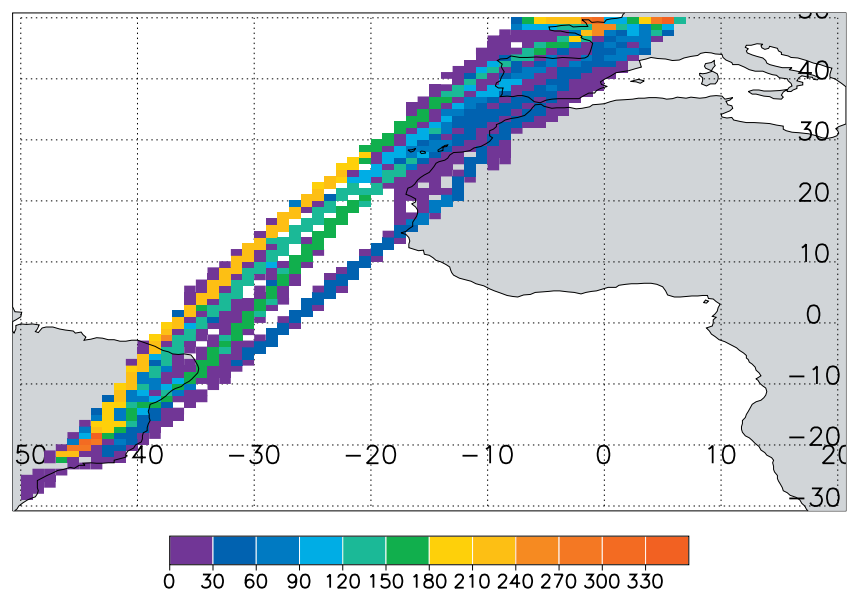

Figure 1. Number of flights in bins of $1^{\circ} \times 1^{\circ}$ latitude by longitude from September 1994 to April 2000.

has taken for air to reach the measurement location from the nearest deep convective event. Satellite-measured cloud top temperatures are used for the location and time of upstream convection and elapsed time from convection to the ozone measurement is obtained from three-dimensional back trajectories. We specifically analyze ozone data that were obtained when the convection was close in time $(0-6 \mathrm{~h})$ and distance to the locations of the measurements. Surface ozone data obtained onboard a commercial ship over the same time period are also used. Aircraft and ship routes from central Europe to South America, and return, cover identical regions. Both data sets are independent of each other and, therefore, a statistical method for the analysis is used. Finally, balloon soundings of ozone and relative humidity over the ITCZ region of the central Atlantic are analyzed. Providing a third and independent data set, these profiles are used to gain insight and quantitative information on entrainment processes in the Atlantic equatorial trough zone.

\section{Data}

\subsection{Data From Aircraft Platform}

[7] Ozone and relative humidity has been measured on board commercial passenger aircraft since 1994 as part of the European MOZAIC (Measurement of Ozone and Water Vapor by In-Service Aircraft) project. MOZAIC is a multinational project, sponsored by the European Commission and major European airlines (Lufthansa, Air France, Austrian Airlines) for the automated measurement of ozone and water vapor from on board five Airbus A340 aircraft on scheduled flights. The project started in August 1994 and over 15,000 flights with more than 100,000 flight hours were made by April 2000, originating from Europe to destinations in North America, South America, Asia, and Africa [Marenco et al., 1998]. Flights either start or end in Europe with destinations on all continents except Australia. The only tropical ocean that is regularly covered is the Atlantic ocean by flights mainly to and from Sao Paulo and Rio de Janeiro (Figure 1). The tracks of those flights are all located in a corridor with a width of about $10^{\circ}$ longitude. There are around 10-20 flights per month from the beginning of the MOZAIC project until spring 2000. A gap of several months occurred during 1995 when none of the 
airlines served Brazil by an aircraft equipped with the MOZAIC instrumentation. The tropics are overflown between about $25^{\circ} \mathrm{S}, 45^{\circ} \mathrm{W}$, and $30^{\circ} \mathrm{N}, 20^{\circ} \mathrm{W}$. However, few flights south of $5^{\circ} \mathrm{S}$ are over the ocean and more than $75 \%$ of those flights are above the South American continent, albeit close to the coast. Most of the measurements are made at cruise altitudes, between 9 and $12 \mathrm{~km}$. Since the outflow of deep convection over the tropical Atlantic is centered at altitudes near $10 \mathrm{~km}$ [Luo et al., 2007], this important altitude is thus directly accessible by the measurements. Within this altitude range the aircraft fly mostly on five distinct pressure levels centered at 288, 262, 238, 217, and $197 \mathrm{hPa}$. The main pressure levels are $238 \mathrm{hPa}$ and $262 \mathrm{hPa}$ (10 and $10.7 \mathrm{~km}$ altitude), each comprising about one third of all measurements.

[8] The principal measurements of the MOZAIC project are aircraft position, wind direction, wind speed, ground speed, air pressure, Mach number, air temperature, relative humidity, and ozone mixing ratio. The accuracy of the relative humidity with respect to ice (RHi) measurements is $5-10 \%$ of RHi [Helten et al., 1998, 1999]. The accuracy of the ozone measurements is $2 \mathrm{ppb}$ [Thouret et al., 1998]. The MOZAIC database (http://mozaic.aero.obs-mip.fr) also contains auxiliary information such as three dimensional 3-d air back trajectories that are computed by Meteo France from data supplied by the European Center for Medium Range Weather Forecast (ECMWF), backward in time from the measurement locations [Simon, 2000].

[9] Measurements of ozone and RHi are made every $4 \mathrm{~s}$. However, data are integrated and stored with a resolution of 1 min which corresponds to a spatial resolution of about $15 \mathrm{~km}$ which is adequate to fully resolve features of ozone and RH. Auxiliary data are also recorded with the same resolution. Since tropical MOZAIC data are taken from within a relatively narrow flight corridor, sampling occurs at nearly identical geographic locations at all seasons. A fairly large number of data points exist if the measurements are binned for sections of latitude, season, etc. The average time resolution of measurements within the flight corridor is $2-3 \mathrm{~d}$ as given by the schedule of the airlines serving Rio de Janeiro and Sao Paulo.

\subsection{Berlin Express Shipboard Data}

[10] Ozone measurements over the tropical Atlantic have been reported by Lelieveld et al. [2004]. For the period under consideration, they were collected onboard the Berlin Express, a container ship, $25 \mathrm{~m}$ above sea surface, by a UV absorption spectrophotometer with its principal technique and accuracy similar to that on the aircraft.

\subsection{Balloon-Borne Data From R/V Polarstern}

[11] Vertical ozone profiles were obtained from $\mathrm{R} / \mathrm{V}$ Polarstern on cruises across the central tropical Atlantic. Electrochemical concentration cells (ECC) were flown on small rubber balloons that also carried standard meteorological instrumentation to measure pressure, temperature and relative humidity and wind direction. The accuracy and precision of ECCs are well documented [Smit et al., 2007]. In the tropical troposphere the ECC achieves an accuracy of $\pm 2 \mathrm{ppb}$, thus being very similar to the accuracy of an UV-absorption instrument.
[12] The initial series of measurements were made in 1987 and 1988 [Smit et al., 1990]. Weller et al. [1996], reported on the soundings that were made until 1994. The series was continued by personnel from the Alfred Wegener Institute (AWI). Data from the 1987 and 1988 campaigns between 0 and $10^{\circ} \mathrm{N}$ are analyzed for this paper. Data from the 1993, 1994, 1996, 1997 and 2000 campaigns were downloaded from the AWI data archive at http:// www.pangaea.de.

\section{Analysis Concept}

[13] MOZAIC aircraft visited a given $1^{\circ}$ latitude-longitude bin of the tropical Atlantic about twice weekly during the time period from September 1995 to April 2000. The measurements thus represent snapshots of ozone, humidity, and the meteorology at observation times, unlike the nearly continuous fields provided by geostationary satellites.

[14] We seek a connection between ozone and humidity in relation to deep convection. Since the measurements take place at random times, the atmosphere is statistically probed by the aircraft instrumentation at various times after (downstream from) the last convective event. The geographical location where the sampled air last encountered convection is called the originating region. Depending on the distance of the originating region to the location of the aircraft at the time of the measurement and the speed of the flow, the ozone and humidity measurements thus take place at various times after the probed air has left the convective area.

[15] Convection is diagnosed by satellite-based measurements of cloud top temperature as obtained from the Eumetsat Climate Data Set (CDS) [European Organization for the Exploitation of Meteorological Satellites, 1999]. High-altitude cloud top temperature (CTT) is derived from brightness temperature that is measured by radiometers on the Meteosat satellites at the 11 and $6.7 \mu \mathrm{m}$ water vapor bands. In addition to the 6.7 and $11 \mu \mathrm{m}$ channel counts, a corrected infrared count (corir) is produced and provided in CDS. It is corrected for surface albedo and semitransparent clouds and clouds that do not cover a whole pixel. The product used for this study is the corir count. As in previous work [Kley et al., 1997], a cloud top temperature of CTT $<240 \mathrm{~K}$ was used to identify areas of deep convection. However, a second necessary condition, namely that CTT had to be equal or lower than the air temperature measured by the aircraft $\left(\mathrm{T}_{\mathrm{AC}}\right)$, was also employed. Since the aircraft-measured temperature did not exceed $231 \mathrm{~K}$ and $236 \mathrm{~K}$ at flight levels 238 and $262 \mathrm{hPa}$, respectively, and on occasion was even lower, all optically thick clouds at and above flight level were counted. For every $160 \times 160 \mathrm{~km}$ satellite segment having several high cloud clusters, an areaweighted average was produced. The raw satellite data have a resolution of $5 \times 5 \mathrm{~km}$. A segment consists of $32 \times 32$ pixels that, through a subdivision in clusters (different surface properties, cloud characteristics, CTT) contains more information than what would have been obtained by a simple averaging process. The percentage area fraction covered with cold clouds per segment was deduced from the number of pixels that are contained in the respective clusters. Only events with a $>70 \%$ cold-cloud coverage in a given segment were analyzed.

[16] Distances or travel times of outflow air from the originating region were derived from three-dimensional, 3-d, backward trajectories calculated by Meteo France 


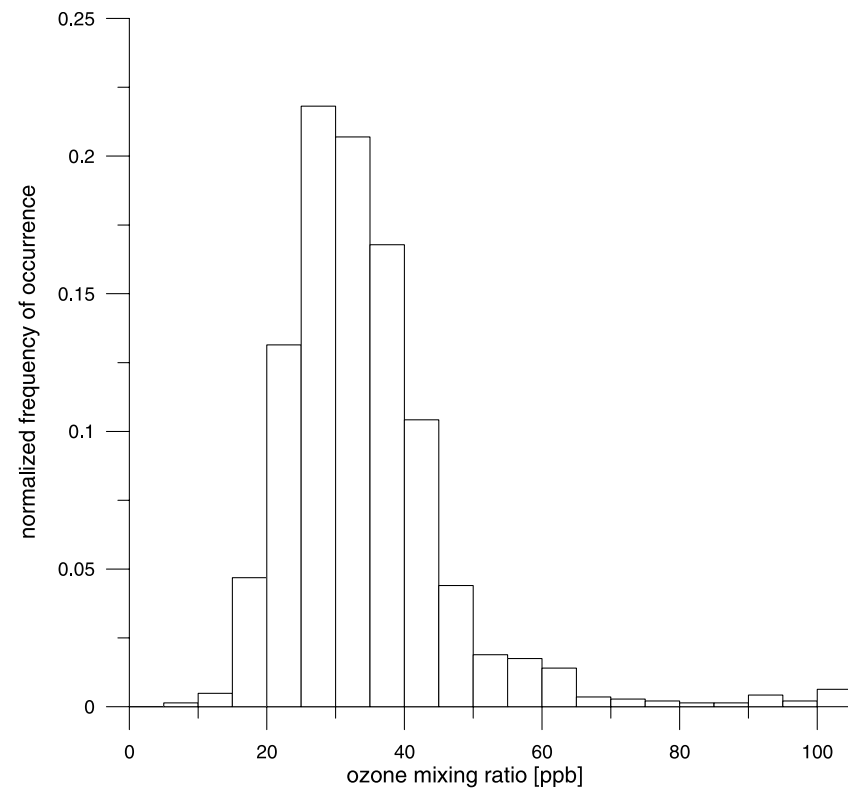

Figure 2. Normalized frequency $(\mathrm{N}=1430)$ of UT near $250 \mathrm{hPa}$ ozone mixing ratio observations, selected to be closest to convection. Ozone mean $=35.0 \mathrm{ppb}$.

from ECMWF analyzed wind fields in the region of MOZAIC [Simon, 2000]. Trajectories are calculated every $15 \mathrm{~min}$ from interpolated $6 \mathrm{~h}$ ECMWF wind fields, and saved every $6 \mathrm{~h}$. A spline interpolation to obtain the position every $30 \mathrm{~min}$ was applied for the present study. The convective origin of a particular trajectory was identified by searching backward along each trajectory for the first point with clouds at $\mathrm{CTT} \leq \mathrm{T}_{\mathrm{AC}}$.

\section{Climatology of UT Ozone and Relative Humidity at and Near Convection From Aircraft, Shipboard, and Balloon Measurements}

[17] The three data sources as described in section 2 are now analyzed in combination to reveal certain aspects and properties of tropical Atlantic convection that are not easily measured in any direct way. Specifically, we study convective entrainment and detrainment through their effects on ozone and RH.

\subsection{Aircraft}

[18] With more than 6 a of MOZAIC measurements, thousands of ozone and humidity data are in the database and can be evaluated. The seasonal variability of the ozone mixing ratio is very weak over the ITCZ region and will not be investigated in this paper. Rather, the data are binned in classes of transport time from very close to $48 \mathrm{~h}$ after convection, neglecting the very weak dependence of convective frequency on season [Luo et al., 2007]. Threedimensional backward trajectories provide elapsed times from a given measurement location to the originating region. A frequency histogram of ozone is shown in Figure 2 for measurements when the aircraft was closest to active convection. Because of the finite resolution of the satellite footprint $(160 \mathrm{~km})$, travel time distances to convection are accurate to within approximately $2 \mathrm{~h}$, given a wind speed of $\mathrm{u} \approx 20 \mathrm{~m} \mathrm{~s}^{-1}$. Figure 2 contains data that were recorded when the aircraft was $160 \mathrm{~km}$, or less, away from active convection. Since commercial aircraft do not fly through the cores of convection and avoid flying through thick anvil clouds the result presented in Figure 2 is representative of ozone mixing ratios close to, but not directly at, convective cores. Results for transport times along trajectories up to $6 \mathrm{~h}$ from convection, including data when the aircraft was closest to convection (Figure 2), are presented in Figure 3. The mean ozone mixing ratio in Figure 2 is $35 \mathrm{ppb}$. The most likely value is very close to $30 \mathrm{ppb}$. The mean of Figure 3 is $35 \mathrm{ppb}$ and the most likely ozone mixing ratio is also $30 \mathrm{ppb}$. Thus the mean ozone mixing ratio does not change from very near to convection to a distance in the direction of outflow of up to $500 \mathrm{~km}$. The histogram of Figure 3 is slightly more skewed toward higher values. Overall, the differences are very small.

[19] A histogram, generated from all data within the $0-$ $10^{\circ} \mathrm{N}, 10-40^{\circ} \mathrm{W}$ region, with no selection for convective origin, is shown in Figure 4. Considerably more $1 \mathrm{~min}$ data $(\mathrm{N}=51983)$ are averaged in Figure 4 than in Figure 3. Another fact also contributes to the higher number of observations in Figure 4: Figures 2 and 3 contain only data from convective mesoscale events, i.e., cloud coverage $>70 \%$ over the originating region. This larger sample, which contains many observations away from deep convection, has a higher mean ozone mixing ratio $(38.8 \mathrm{ppb})$ and a far greater percentage of observations in the 40-80 ppb range. This result, combined with the results in Figures 2 and 3, indicates that convection serves to locally reduce the ozone mixing ratio in the upper troposphere.

[20] For convective events more than $6 \mathrm{~h}$ away, it was observed that the mean ozone mixing ratio increases with time (distance) from the location of convective origin. This is shown in Figure 5, which also contains a least squares fit to the data. The increase is $6 \mathrm{ppb}$ over $48 \mathrm{~h}$. Because the number of observations decreases from 3700 close to convective origins, to only 230 , for a transport time of

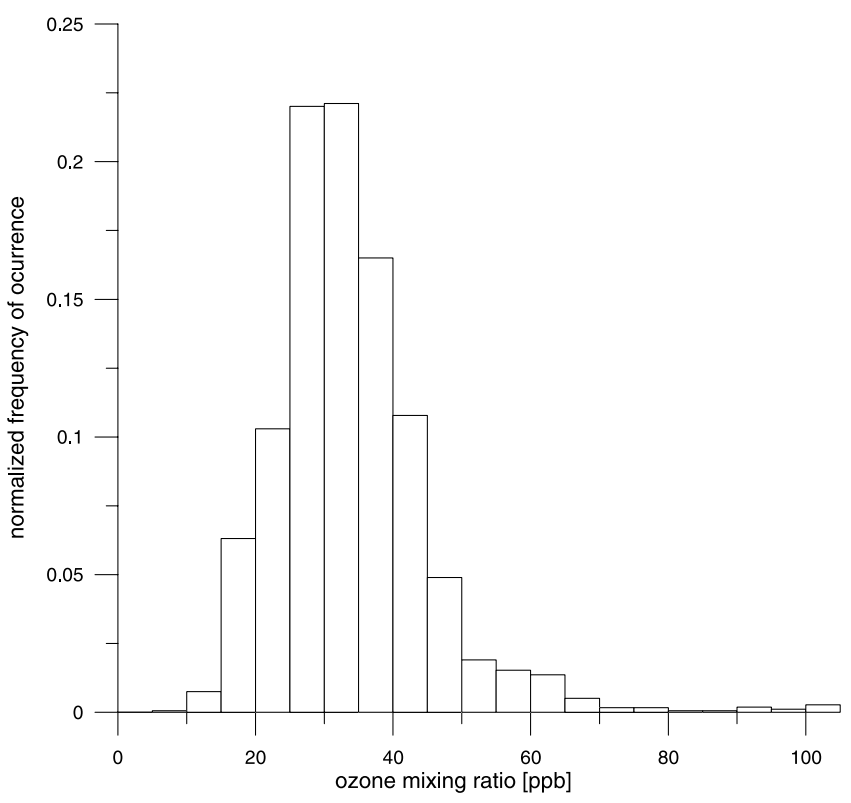

Figure 3. As in Figure 2 but for convection up to $6 \mathrm{~h}$ away from locations of observations $(\mathrm{N}=3739)$. Ozone mean $=$ $34.4 \mathrm{ppb}$. 


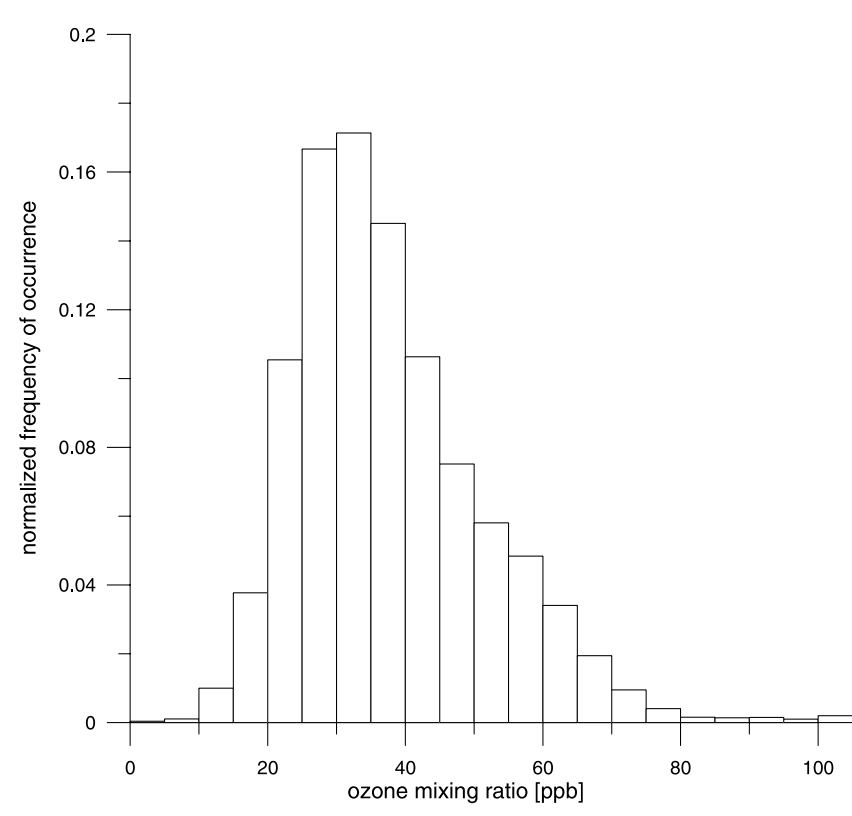

Figure 4. UT (9-12 km) ozone mixing ratio histogram $(\mathrm{N}=51983)$. Data not selected with regard to convection. Ozone mean $=38.3 \mathrm{ppb}$.

$48 \mathrm{~h}$, this increase is not evident solely from analyzing histograms. Possible reasons for the observed increase are photochemical ozone production, mixing of convective outflow air with ozone-richer ambient air and/or downward, nonisobaric, transport from ozone-richer levels above the aircraft altitude at origin.

[21] A contour map of ozone versus relative humidity from observation $0-6 \mathrm{~h}$ away from convection is shown in
Figure 6. As in Figures 2 and 3 the segmental coverage by cold cloud was $>70 \%$. Figure 6 clearly shows that deep convection is centered at a relative humidity over ice of $110 \%$ at the $250 \mathrm{hPa}$ pressure level. The sharpness of the peak at $110 \% \mathrm{RHi}$ and the close association between low ozone and deep convective outflows (high RHi) is striking. The spread of the ozone mixing ratio from $\sim 10$ to $70 \mathrm{ppb}$ with a maximum of the distribution at $30 \mathrm{ppb}$ corresponds to that shown as a histogram in Figure 3. A physical explanation involves variability of surface ozone. It is discussed in the following section. The spread of humidity from 40 to $150 \%$ is obviously not related to the approximately constant relative and specific humidity in surface air. Rather it indicates substantial water vapor related small-scale inhomogeneities in the convective outflow region around a most likely value of $110 \%$ RHi. A histogram of RHi (not shown) has a narrow, nearly Gaussian, shape that peaks at $100-110 \%$ RHi with a width at half maximum of $40 \%$.

\subsection{Shipboard}

[22] The UT ozone histograms in Figure 3 contain data from a time period of almost 6 a, taken during all seasons. At a sample size of nearly 4000, all from nearby deep convection, it allows an assessment of the influence of convection on UT ozone near $250 \mathrm{hPa}$. An identical histogram from ozone observations in MBL air would provide strong evidence that undiluted MBL air has been transported to the UT [see Kley et al., 1996, 1997]. In other words: Are the UT ozone histograms of Figures 2 and 3 true representations of MBL ozone or has the ozone mixing ratio changed during the vertical convective transport of air parcels? This question can be answered from the Berlin Express shipboard data as reported by Lelieveld et al. [2004]. They were obtained on cruise paths

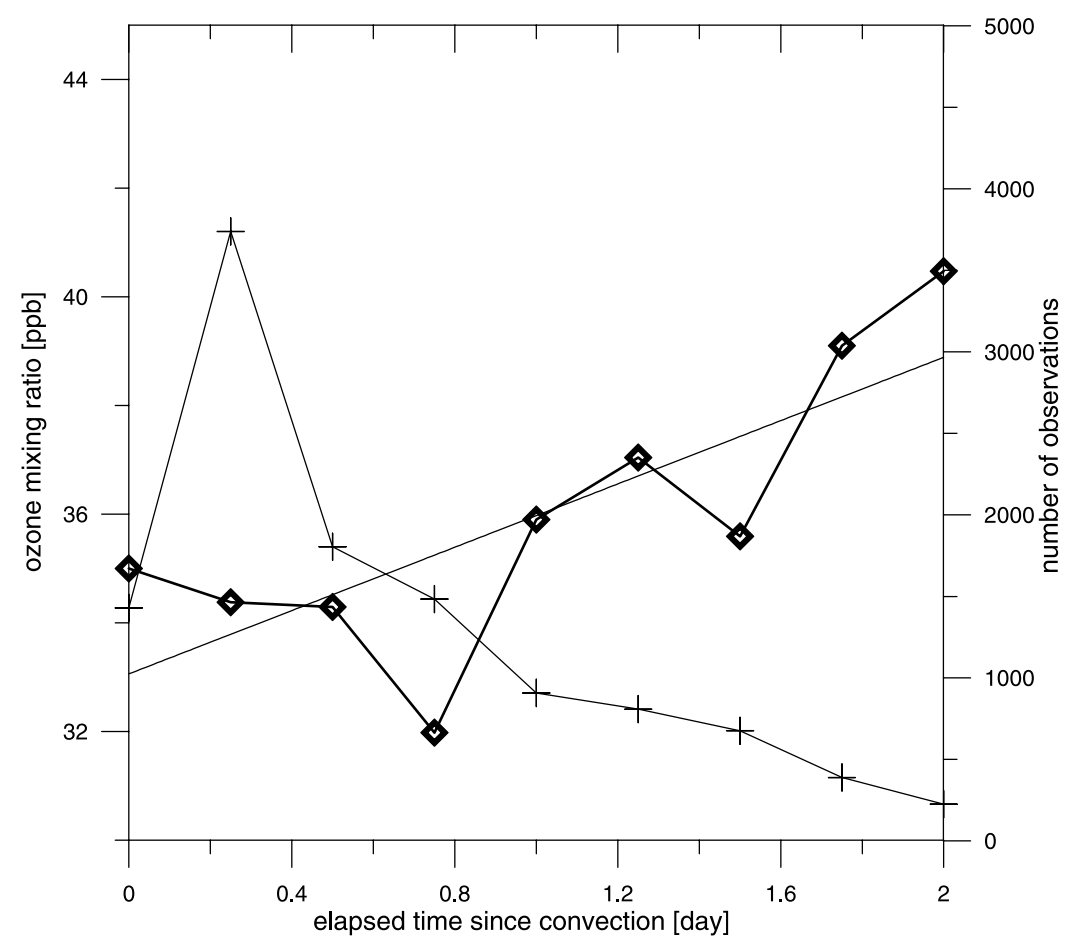

Figure 5. Ozone mean mixing ratio (rhombi) from observations selected according to time (days) since probed air was in convection. Number of observations are indicated by crosses. Linear least squares fit is indicated by line. 


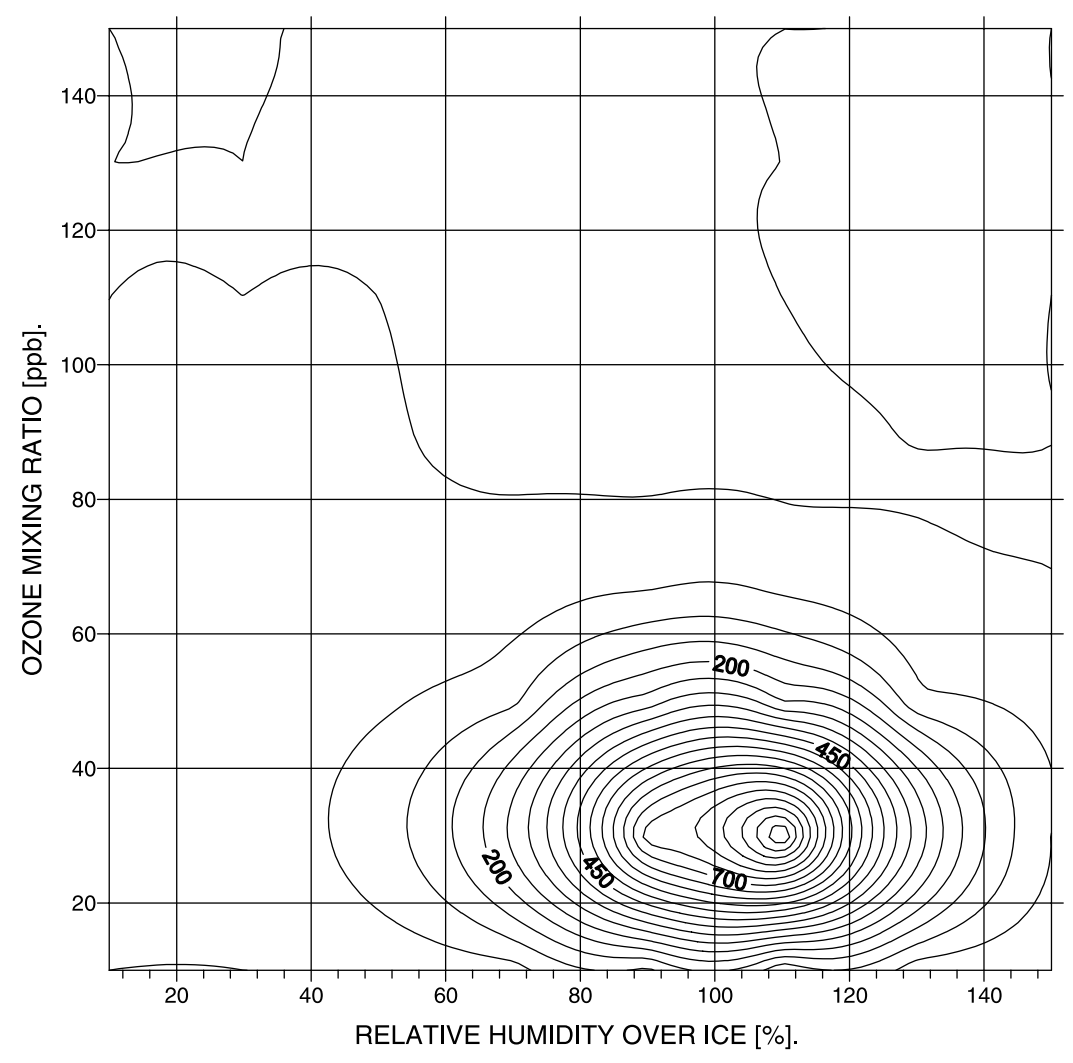

Figure 6. Contour map of frequency of RHi/ozone mixing ratio observations for elapsed time between 0 and $6 \mathrm{~h}$ since probed air had been subjected to convection. Coverage by cold cloud $(\mathrm{T}<240 \mathrm{~K})$ in satellite segment $(160 \times 160 \mathrm{~km})$ of originating region was $>70 \%$. Figures on contours are number of observations. Tick marks are bin centers.

similar to MOZAIC, and they also have a similar measurement frequency over the tropical Atlantic. Therefore MOZAIC data, and ship data, after selection for identical geographical conditions $\left(0-10^{\circ} \mathrm{N}, 26-10^{\circ} \mathrm{W}\right)$, are compared for convective periods. A histogram from shipboard data is shown in Figure 7. The ozone mean mixing ratio is $27 \mathrm{ppb}$ and thus lower by $7 \mathrm{ppb}$ than the mean at outflow level. The most likely mixing ratio is $10 \mathrm{ppb}$ lower than that at outflow. Overall, the shapes of both the aircraft and ship distributions are similar. The main difference is in the $<25 \mathrm{ppb}$ bins which are relatively more populated in the ship data set. The shipboard data are hourly means and are not selected for convection. However, over a time period of several years (with 24 daily measurements) convection is randomly sampled; thus the histogram is representative of the surface ozone mixing ratios.

\subsection{Balloon}

[23] Initial humidity/ozone soundings over the central Atlantic were obtained during the 1987/1988 Polarstern $\mathrm{N} \leftrightarrow \mathrm{S}$ cruises at $30^{\circ} \mathrm{W}$ [Smit et al., 1990]. During these campaigns soundings were made every $6 \mathrm{~h}$ over a period of 3 weeks on each campaign. The resulting height-latitude cross sections of the ozone mixing ratio and of moist static energy $\left(h=g ~ z+c_{p} T+L q\right)$ from the 1988 September/ October campaign are shown in Figures 8 and 9, respectively. One of the most striking features from Figure 8 is the low ozone concentration within the $\operatorname{ITCZ}\left(0-10^{\circ} \mathrm{N}\right)$ that extends from the MBL all the way up to $14 \mathrm{~km}$ altitude resembling a giant convective plume. An ozone cross section showing a similar feature was reported by Thompson et al. [2000]. Sandwiching the giant plume are two sectors with high ozone concentration around $10^{\circ} \mathrm{S}$ and $20^{\circ} \mathrm{N}$ that descend from the upper troposphere. (Note that this giant plume actually consists of multiple mesoscale convective system (MCSs) rather than a single convective plume. It also includes convection from tropical depression "Isaac" that is turning into a tropical storm.) This ozone morphology clearly reveals the characteristics of the Hadley Cell (rising motion near the equator and sinking motion in the subtropics). The cross section of moist static energy is compared to that of ozone and discussed in section 6.

[24] Both ozone and moist static energy in Figures 8 and 9 point to some dry air intrusion in the middle to lower troposphere. Dry air intrusions can be inferred from higher ozone concentration characteristic of the UT penetrating from the subtropics into the giant convective plume, diluting it. More will be said about this process later.

[25] Guided by the large-scale ozone morphology of Figure 8, we divided the Polarstern soundings made between 1987 and 2000 during the months of February, April, May, June, September and October in 2 classes. The first class comprises soundings within the giant plume region $\left(0-10^{\circ} \mathrm{N}\right)$. This class contains 22 soundings.

[26] Means and standard deviations of relative humidity and ozone profiles for soundings that were made within the plume region are shown in Figure 10. The ozone mixing 


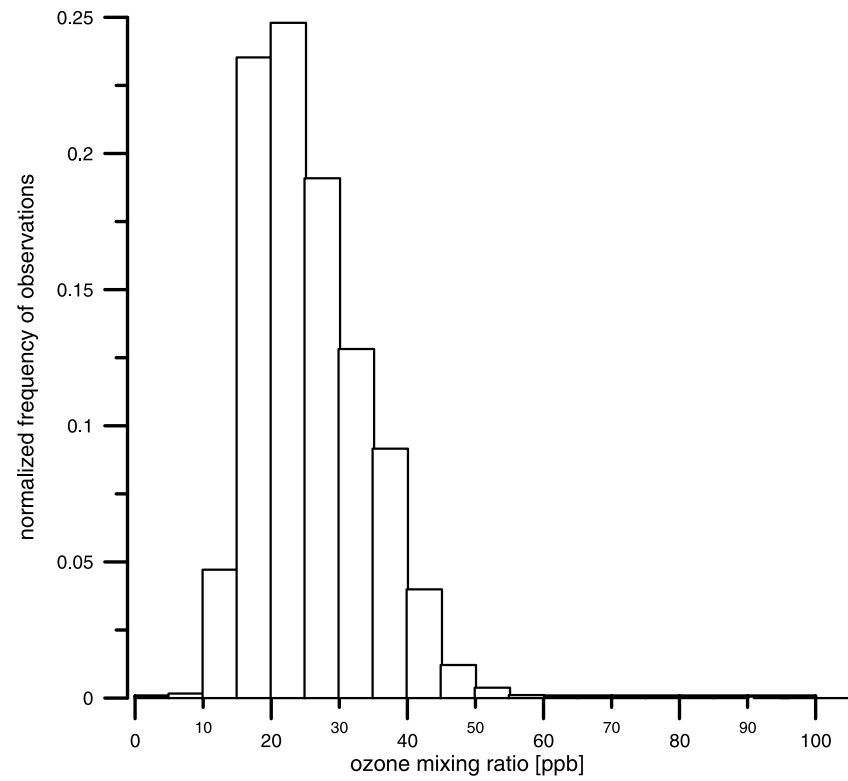

Figure 7. Normalized frequency ( $\mathrm{N}=1802)$ of hourly means of ozone observations from on board Berlin Express (1995-2000). Ozone mean $=27.0 \mathrm{ppb}$.

ratio increases from $22 \mathrm{ppb}$ at surface to $45 \mathrm{ppb}$ at $700 \mathrm{hPa}$ and stays below $55 \mathrm{ppb}$ all the way up to $200 \mathrm{hPa}$. The profile is characterized by two features anticorrelated with relative humidity: where $\mathrm{RH}$ has minima, ozone has maxima, and vice versa. The first feature, a strong anticorrelation, is centered at $700 \mathrm{hPa}$. A weaker anticorrelation is centered at $450 \mathrm{hPa}$, somewhat displaced to higher pressure, relative to the second humidity minimum.

[27] The humidity profile is characterized by a region of drying between 900 and $600 \mathrm{hPa}$ (centered near $700 \mathrm{hPa}$ ) in an otherwise smoothly decaying profile from about the usual $80 \%$ at surface to $50 \% \mathrm{RHi}$ at $250 \mathrm{hPa}$. There is an indication for another dry region, ranging from 600 to $300 \mathrm{hPa}$. The profile may alternatively be characterized as having a moist anomaly centered near $570 \mathrm{hPa}$.

[28] The observed anticorrelation of humidity and ozone suggests either an intrusion of dry air with an enhanced ozone content near $700 \mathrm{hPa}$ and, similarly but weaker, near 400-500 hPa. Similar dry intrusions have been observed over the western equatorial Pacific [Parsons et al., 2000; Numaguti et al., 1995]. Or an alternative explanation for the anticorrelated features in these profiles is that there is a preferential detrainment of moist, low-ozone, MBL air from cumulus clouds passing through or terminating near the melting layer [Johnson et al., 1996, 1999]. The arrows in Figure 10 serve to illustrate this possibility. In support of the idea, Newell et al. [1996] report aircraft observations of a peak in the number of layers of water vapor-rich, ozonepoor air between 4 and $6 \mathrm{~km}$ over the tropical north Pacific, indicative of convective transport from the MBL.

[29] Figure 10 also includes standard deviations about the RH and ozone means. They show that the details of these features are robust. Since the profiles are from soundings ranging from $0.1^{\circ} \mathrm{S}$ to $10^{\circ} \mathrm{N}$, and measured at nearly all seasons, they are argued to be general features of the tropospheric humidity and ozone profiles over the ITCZ region of the (eastern) Atlantic.
[30] An individual profile from a sounding, made on 28 September 1988 is shown in Figure 11. This was one of the most convective soundings that were obtained over the period from 1987 to 2000 . The active convection can be inferred, apart from normal meteorological information, from the very large values of relative humidity which are mostly above $80 \%$ up to $300 \mathrm{hPa}$ (the humidity sensor on the meteorological package was a standard Humicap $A^{\circledR}$ which, below $400-300 \mathrm{hPa}$, is not reliable) and by the fact that the observed ozone mixing ratio at $250 \mathrm{hPa}$ is virtually identical to the climatological values (indicated by rhombi in Figure 11) from MOZAIC observations for convection.

[31] There is a substantial difference between the most convective profile (Figure 11) and the mean profile (Figure 10). This can be understood from the fact that Figure 10 contains soundings that, on the one hand, have been made in the giant plume region but, on the other hand, were made at random times and thus not having been selected for convective conditions. The profiles of Figure 10 are a composite of soundings close in time or distance to convection. This is also implied by looking at the standard deviations of the humidity and ozone profiles. More convective soundings show much higher values of relative humidity while, at the same time, the ozone profiles are shifted toward low values.

[32] The mean sounding (42 individual soundings), from the subsiding branch of the Hadley cell, just north of the border of the giant plume $\left(13-30^{\circ} \mathrm{N}\right)$ is shown in Figure 12 . The humidity profile shows low values throughout the troposphere, characteristic for conditions of suppressed convection while there is a steady increase of ozone with height.

\section{Mechanisms and Quantification of Convective Entrainment}

[33] Two mechanisms in principle can explain the existence of ozone mixing ratios in the convective outflow regions that are higher than surface values. The first one involves the fact that deep convection lifts air from the

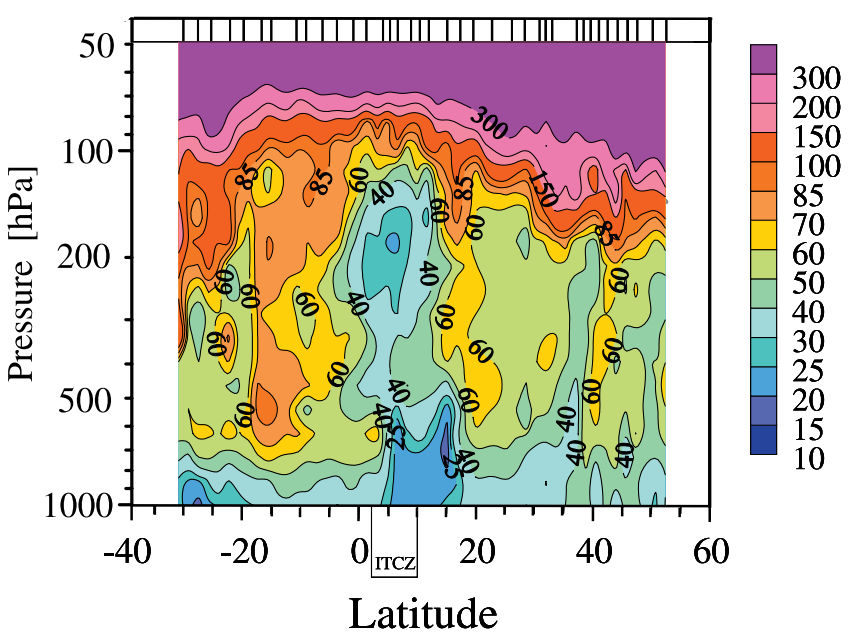

Figure 8. Latitude/height cross section of ozone mixing ratio (ppb) over central Atlantic at $30^{\circ} \mathrm{W}$. Soundings were made from on board R/V Polarstern in September/October 1988 and are indicated by short vertical line segments at top of figure. 


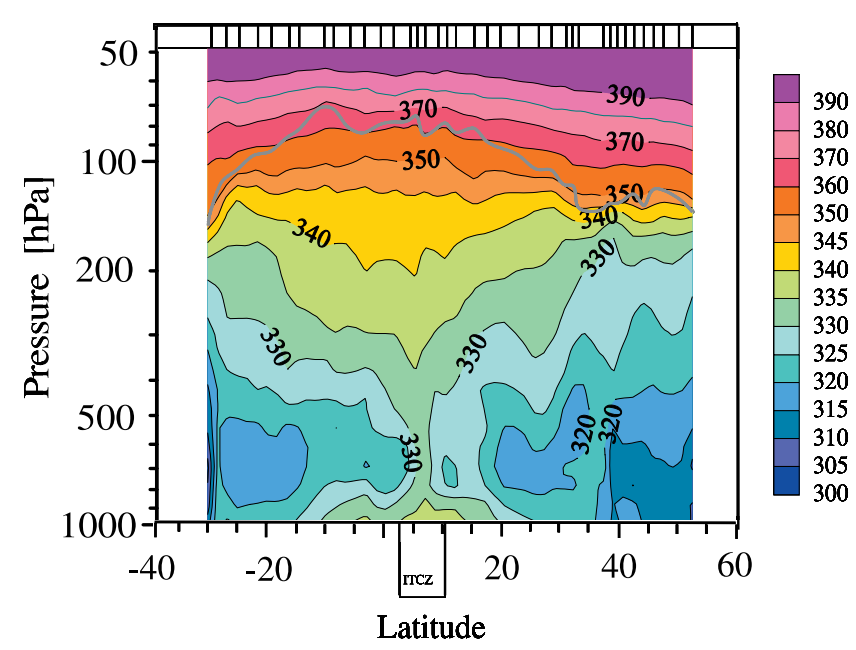

Figure 9. As in Figure 8 but for moist static energy h $(\mathrm{kJ} / \mathrm{kg})$. Thermal tropopause indicated by thick solid line.

MBL, and not just from the surface. So, if the MBL is not thoroughly mixed, and higher ozone exists in the MBL, the ozone mixing ratio of the UT outflow would be somewhat higher. However, details of the 1987/1988 ozone soundings [Smit, 2004] show virtually constant ozone mixing ratios in the ITCZ region from surface to about $900 \mathrm{hPa}$ which speaks against this possibility.

[34] The second scenario involves entrainment of free tropospheric air (above MBL) into the convective core. A comparison of Figure 7 to Figure 2 suggests that a UT histogram, very similar to that from MOZAIC data can be generated from the ship distribution by an additive trans- formation such that $\mathrm{UT}\left(\mathrm{O}_{3}\right)_{\text {convection }}=\operatorname{MBL}\left(\mathrm{O}_{3}\right)+\boldsymbol{\alpha}$. In terms of a process a similar result would be achieved if, during active convection, ozone amounts of $\boldsymbol{\alpha} \mathrm{ppb}$ would be added to air parcels that are lifted to the UT with an initial MBL distribution according to Figure 7. Thus the enhancement of the mean ozone mixing ratio at the convective outflow over the mean of the MBL would be the result of entrainment of air into the rising convective plume in the middle troposphere.

[35] The initial soundings from 1987/1988 over the Atlantic [Smit et al., 1990] and soundings over the central Pacific [Kley et al., 1996, 1997] gave hints for entrainment between 700 and $800 \mathrm{hPa}$. The present results put these hints on a firm basis. The balloon soundings (Figure 10) show enhanced ozone/low RH between 900 and $400 \mathrm{hPa}$ in the climatological mean which suggest that tropospheric air from above the MBL is laterally advected and entrained into the rising convection.

[36] A simple bulk model can be used to interpret a combination of the MOZAIC, Berlin Express and R/V Polarstern results: The model has three layers. Layer 1 is the MBL. Convection lifts air from the MBL and discharges it at the convective outflow level (layer 3). Layer 2 is the middle troposphere from where air is entrained into the convective plume. The ozone mixing ratio at the outflow level of convection is $\mu_{3}=\left(\Phi_{1} \mu_{1}+\Phi_{2} \mu_{2}\right) /\left(\Phi_{1}+\Phi_{2}\right)$ where $\Phi_{1}$ is the vertical mass flux of MBL air, $\Phi_{2}$ is the net entrainment mass flux and $\mu_{1}, \mu_{2}$ and $\mu_{3}$ are the ozone mixing ratios of $\mathrm{MBL}$ air, middle tropospheric air, and outflow air, respectively. Mass balance requires that $\Phi_{3}=$ $\Phi_{1}+\Phi_{2}$, where $\Phi_{3}$ is the flux at outflow level. Since $\mu_{1}, \mu_{2}$ and $\mu_{3}$ are known from the measurements, the ratio of the entrainment to MBL flux can be determined. From the

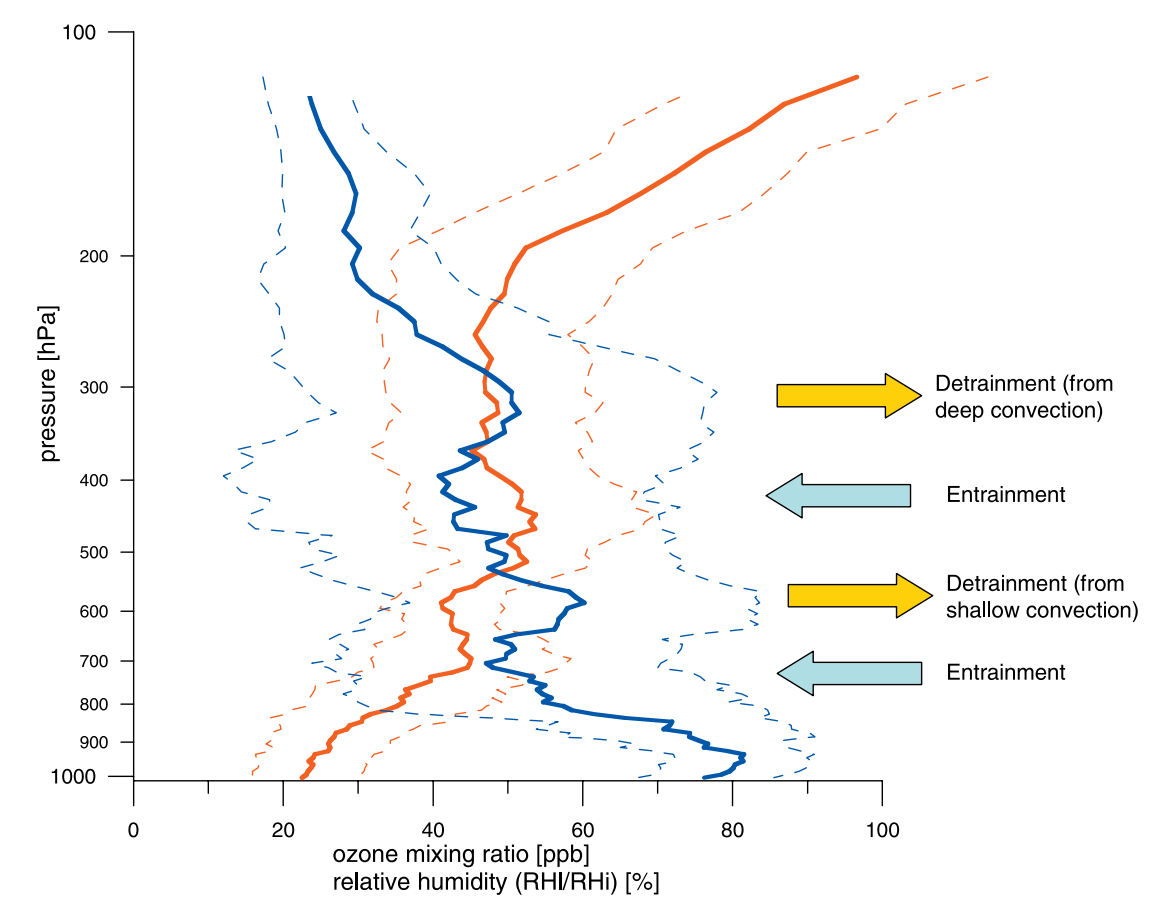

Figure 10. Mean ozone (red, solid), $\mathrm{RH}_{\mathrm{i}}$ (blue, solid) and standard deviation (dashed) profiles, $\left(0-10^{\circ} \mathrm{N}\right)$, from 1987-2000 balloon soundings made from on board R/V Polarstern. Regions of entrainment/ detrainment are indicated by arrows. 


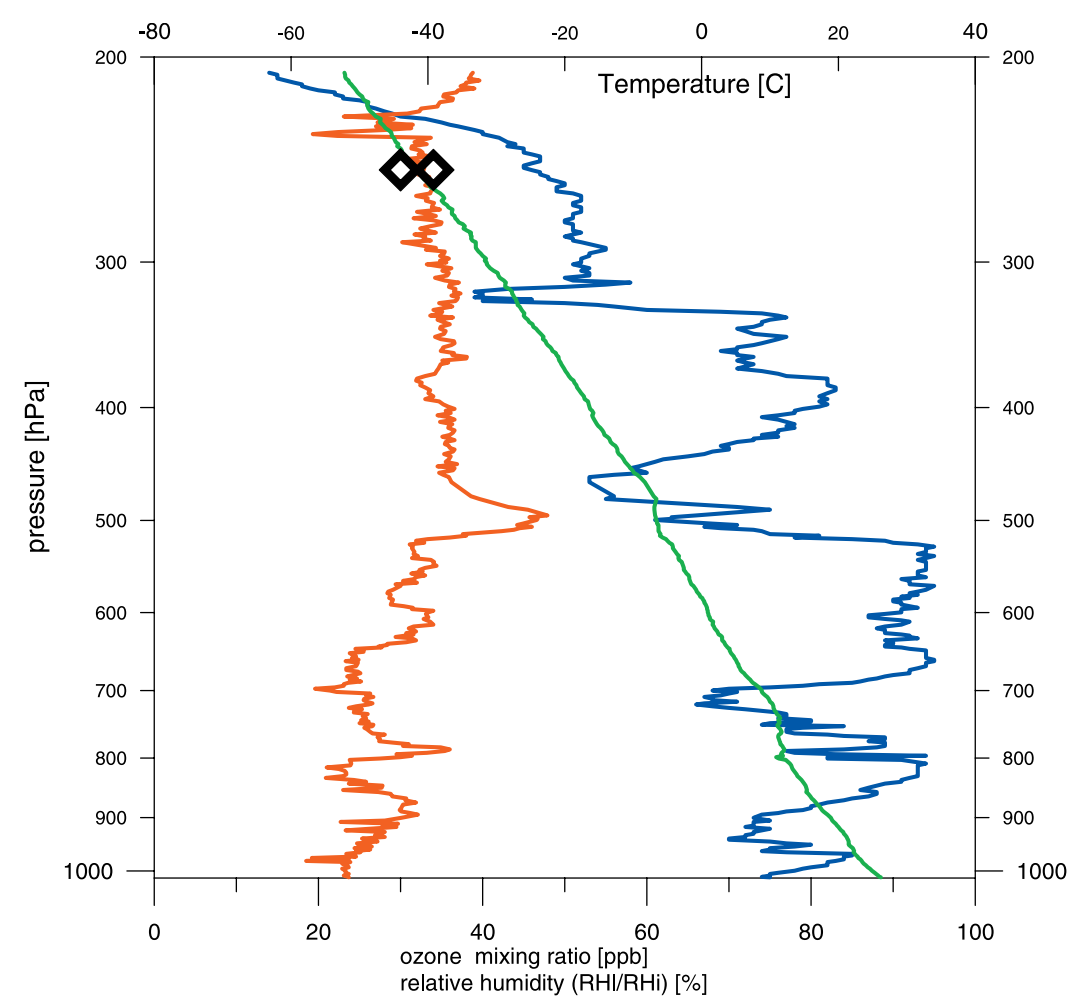

Figure 11. Ozone (red), relative humidity (blue) and temperature (green) of sounding from R/V Polarstern on 28 September 1988 at $0.5^{\circ}, 13^{\prime} \mathrm{N} ; 30^{\circ} \mathrm{W}$. Climatological mean and most likely ozone mixing ratio from MOZAIC observations, downstream from and close $(0-6 \mathrm{~h})$ to deep convection (rhombi).

Berlin Express and MOZAIC climatologies we have $\mu_{1}=$ $27 \mathrm{ppb}$ and $\mu_{3}=34 \mathrm{ppb}$. As far as entrainment is concerned, from Figure 10 a pressure range between 900 and $400 \mathrm{hPa}$ is implied as the most active interval which, in turn, suggests an ozone range $\mu_{2}=(38-59) \mathrm{ppb}$ (from Figure 12.). The ratio of entrainment to trade wind (MBL) mass flux is

$$
\frac{\Phi_{2}}{\Phi_{1}}=\frac{\left(\mu_{1}-\mu_{3}\right)}{\left(\mu_{3}-\left\langle\mu_{2}\right\rangle\right)}
$$

where $\left\langle\mu_{2}\right\rangle$ is the mass flux weighted mixing ratio

$$
\left\langle\mu_{2}\right\rangle=\frac{\int \mu_{2} \frac{\partial \Phi_{2}}{\partial \mathrm{p}} \mathrm{dp}}{\int \frac{\partial \Phi_{2}}{\partial \mathrm{p}} \mathrm{dp}}
$$

In order to analytically solve for $\left\langle\mu_{2}\right\rangle$ the differential mass flux, $\partial \Phi_{2} / \partial \mathrm{p}$, must be known in addition to the ozone mixing ratio between 400 and $900 \mathrm{hPa}$. If the net entrainment mass flux can be approximated by a linear function of pressure, then $\left\langle\mu_{2}\right\rangle=48 \mathrm{ppb}$ is obtained, independent of the magnitude of $\Phi_{2}$. Under this assumption the ratio of entrainment to MBL mass flux of $\Phi_{2} / \Phi_{1}=0.50$ and $\Phi_{3}=1.5$ $\Phi_{1}$ is obtained.

[37] The bulk cloud ensemble model of Yanai et al. [1973] is relevant in this context. They consider an ensemble of clouds of different heights, each behaving as an entraining plume and detraining in an infinitesimal layer at cloud top. Therefore, if all the clouds are added together, each with its own entrainment profile and cloud top de- trainment, then bulk entrainment and detrainment profiles of the cloud ensemble are obtained. This bulk model seems to be a better concept for the ITCZ complex, but there are several assumptions to obtain full solutions. In addition, the data set of individual ITCZ ozone profiles is quite small and we are not in possession of the apparent heating rate, Q1, and the apparent moisture sink, Q2, which are needed to make effective use of Yanai's approach. Yanai's bulk cloud model yields a bulk entrainment rate ( $\varepsilon$ in his paper) that varies with pressure. Further, their average vertical profile of the cloud mass flux, $\mathrm{M}_{\mathrm{c}}$, is a negative function of pressure above $400 \mathrm{hPa}$ and larger than the average residual mass flux, $M$ in the environment. They note that this result means that the upward mass flux in cumulus clouds is larger than the mass flux required from large-scale horizontal convergence. Altogether Yanai et al.'s results justify our above approximation regarding the pressure dependence of the net entrainment flux.

[38] The important result from using ozone instead of large-scale heating and moisture budgets is that the bulk upward flux in cumulus convection over the central Atlantic exceeds the horizontal convergence flux by $50 \%$ and that, as a consequence, the outflow flux in the upper troposphere, $\Phi_{3}$, is larger by $50 \%$ as well.

[39] We have not used average or individual ozone profiles from within the giant plume region but relied instead on climatological ozone mixing ratios at MBL and outflow altitude, respectively. Details in the vertical structure of such profiles (Figure 10) indicate that entrainment/ detrainment depends on pressure and/or temperature. Pro- 


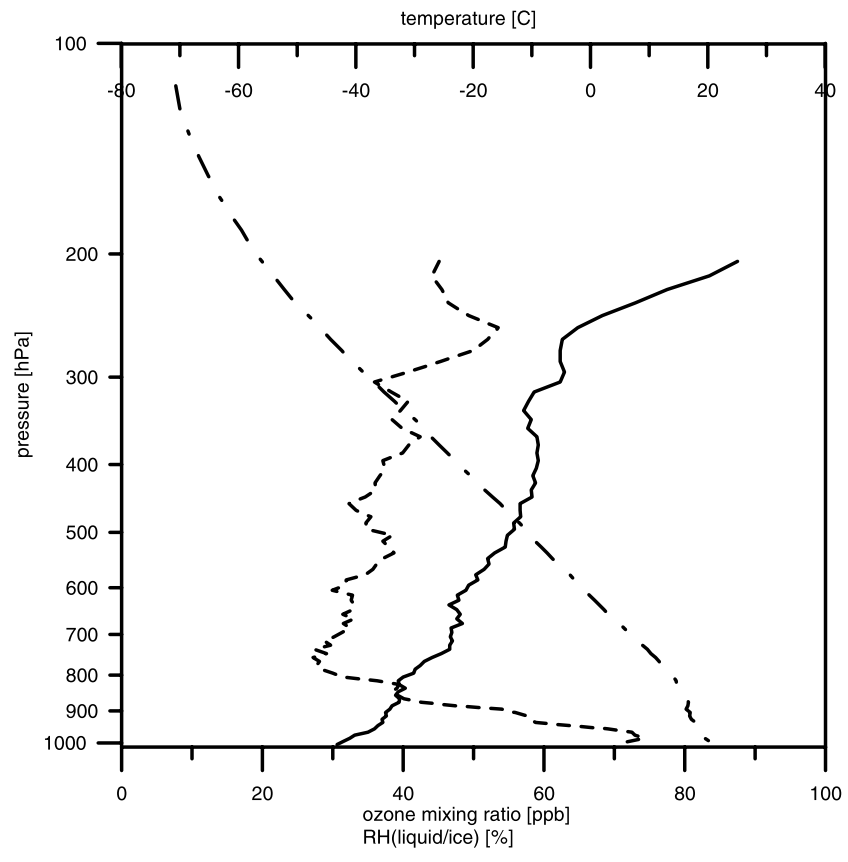

Figure 12. Ozone mean (solid), $\mathrm{RH}_{\mathrm{i}}$ (dashed) and temperature (dot-dashed) profiles, averaged over $13-30^{\circ} \mathrm{N}$, from 1987-2000 AWI data.

cesses that control entrainment/detrainment fluxes are discussed in section 4.3.

\section{Discussion}

[40] Moist static energy, h, is often used to illustrate thermal features of the mean equatorial trough zone [Riehl and Malkus, 1958]. Our results show that an ozone cross section has an advantage over cross sections of h: Some fine structure is captured in Figure 8 that is not obvious from the moist static energy cross section (Figure 9). For example, cumulus congestus type convection (extending to about $5 \mathrm{~km}$ ) at $15^{\circ} \mathrm{N}$ and strong subsidence at $20^{\circ} \mathrm{N}$ can only be identified in the ozone cross section map. Although moist static energy is also a semiconservative variable on this timescale (apart from mixing), the differences between Figure 8 and Figure 9 suggest that moist static energy is less effective for this purpose than ozone. This can be understood through the following argument: Tropospheric moist static energy has background values on the order of $330-340 \mathrm{~kJ} / \mathrm{kg}$. Convective plumes have an only slightly higher energy, i.e., a few degrees warmer plus some contribution from water vapor, resulting in a surplus in moist static energy of around $10 \mathrm{~kJ} / \mathrm{kg}$ (calculated assuming saturated air with a few degrees of temperature surplus). This small fractional difference $(\sim 3 \%)$ is not readily identified in the moist static energy map. Moreover, the vertical gradient of the background moist static energy structure is small in terms of fractional change (from $330 \mathrm{~kJ} / \mathrm{kg}$ at the surface to $340 \mathrm{~kJ} / \mathrm{kg}$ at $250 \mathrm{hPa}$ ). Also, it does not increase or decrease monotonically with height but has a minimum in the middle troposphere. Consequently, overturning circulation is not easily mapped out through the cross section of h. UT ozone concentration, on the other hand, has a background value of about 50-60 ppb, much larger than that inside convective plumes $(\sim 20-30 \mathrm{ppb})$. Further, the vertical gradient of background ozone is also steep. Hence both rising and sinking motions easily stand out in the ozone cross section, making it a better tracer for mapping tropical circulation than moist static energy. Furthermore, moist static energy is nonconservative on a timescale of several days because of radiative effects, which operate, on average, at a cooling rate of $1 \mathrm{~K} / \mathrm{d}$ in the tropical troposphere. (It took R/V Polarstern 2-3 d (i.e., 27 to 29 September 1988) to cross the Atlantic ITCZ and to collect the soundings as shown in Figures 8 and 9.) This would further complicate and blur the already small contrast in $\mathrm{h}$ between convective and nonconvective regions. The timescale of ozone depletion in the upper tropical troposphere is months, approaching 1 a [Smit, 2004]. Photochemical ozone production is also slow. Since an upper limit is roughly $2 \mathrm{ppb} \mathrm{d}^{-1}$ (Figure 5) the dynamics of the circulation are also better mapped by the ozone cross section. A study of tropical free tropospheric ozone therefore offers a unique opportunity providing additional insight into the nature of tropical circulation systems.

[41] Moisture (in terms of either specific or relative humidity) is not a conserved quantity. It cannot be used to map convection. However, simultaneous measurements of $\mathrm{RH}$ and ozone mixing ratio has added values as shown in previous sections. For example, vertical profiles of $\mathrm{RH}$ and ozone can be used to identify the preferred or most pronounced levels of entrainment and detrainment as they are usually negatively correlated at these levels. It is also found in this study that RH of the outflow air has a distinct mode at $110 \%$ RHi, together with a large spread to lower and higher humidity. As Figure 12 shows, the humidity of the entrained air is low, at $30-40 \%$. Isobaric entrainment of $\sim 30 \%$ humidity air into the trough zone above MBL lowers the humidity of the giant plume to approximately $75 \%$ and an adequate amount of liquid water, transported in convective cores, is used to compensate by evaporation for the low humidity of the entrained air. Since it takes less than $1 \mathrm{~km}$ of vertical ascent to attain again saturation in the rising air from initially $75 \% \mathrm{RHi}$, further ascent in air devoid of ice condensation nuclei could create large supersaturation over ice up to saturation over liquid. Therefore supersaturation over ice is feasible. However, it is difficult to come up with a scenario for dry air in the convective outflow. Small-scale convection-induced subsidence might be involved. This phenomenon will be further discussed in a separate study that combines satellite observations of convection and MOZAIC RH measurements.

\section{Conclusions}

[42] Tropospheric tropical ozone can be used as a quasiconservative quantity in the context of deep convection. A statistical analysis of ozone data from commercial aircraft, ship board and balloon platforms shows that mean ozone mixing ratios at outflow altitude $(\sim 10 \mathrm{~km}, \sim 250 \mathrm{hPa})$ of cumulonimbus convection over the central Atlantic ocean are larger by $7 \mathrm{ppb}$ than those at and near sea surface. Since photochemical ozone production occurs on a much longer than convective timescale, the source of the additional ozone is attributed to entrainment of higher ozone mixing ratio into the rising convection. An ozone mixing ratio latitude by altitude cross section depicts the large-scale 
features of the Hadley Cell with rising air over the ITCZ region and descending air over the subsiding branch. The subsiding branch supplies enhanced ozone and low humidity air to the middle troposphere from where it is transported to the ITCZ. The preferred or most pronounced levels of entrainment are identified to be near $700 \mathrm{hPa}$ and from 500 to $400 \mathrm{hPa}$, as indicated by layers of simultaneous drying and enhanced ozone mixing ratio in otherwise smooth profiles. There are also indications of convective detrainment at around $600 \mathrm{hPa}$ and $300 \mathrm{hPa}$, which may correspond to shallow and deep convection, respectively. A flux model, in conjunction with climatological ozone mixing ratios in MBL and outflow air, respectively, is used to estimate the ratio of the bulk entrainment mass flux $\left(\Phi_{2}\right)$ between 900 and $400 \mathrm{hPa}$ to the initial convective mass flux from the MBL below $\left(\Phi_{1}\right)$. The ratio is calculated to be $\Phi_{2} /$ $\Phi_{1}=0.50$, suggesting that the bulk entrainment rate over the tropical Atlantic is about $50 \%$. The RHi of air at the convective outflow is centered at $110 \%$, with a considerable range from a low near $40 \%$ to a high near $150 \%$.

[43] Acknowledgments. This work was supported by the National Science Foundation (NSF) under grant ATM-0444244. We thank Air France, Austrian Airlines and Lufthansa for carrying the MOZAIC instrumentation on their scheduled flights. Thanks go to Peter von der Gathen of AWI, Potsdam, for providing R/V Polarstern ozone sounding data and to Jos Lelieveld of Max-Planck Institut für Chemie, Mainz, for supplying ozone data from the Berlin Express.

\section{References}

Brown, R. G., and C. Zhang (1997), Variability of mid-tropospheric moisture and its effect on cloud-top height distribution during TOGA COARE, J. Atmos. Sci., 54, 2760-2774.

Crutzen, P. J. (1979), The role of $\mathrm{NO}$ and $\mathrm{NO}_{2}$ in the chemistry of the troposphere and stratosphere, Annu. Rev. Earth Planet. Sci., 7, 443-472.

Derbyshire, S. H., I. Beau, P. Bechtold, J. Y. Grandpeix, J. M. Piriou, J. L. Redelsperger, and P. Soares (2004), Sensitivity of moist convection to environmental humidity, Q. J. R. Meteorol. Soc., 130, 3055-3079.

DeMott, C. A., and S. A. Rutledge (1998), The vertical structure of TOGA COARE Convection. Part II: Modulating influences and implications for diabatic heating, J. Atmos. Sci., 55, 2748-2762.

European Organization for the Exploitation of Meteorological Satellites (1999), Meteosat Archive User Handbook, Issue 2.2, Meteorol. Archive and Retrieval Facility, Eur. Org. for the Exploitation of Meteorol. Satell., Darmstadt, Germany.

Houze, R. A., Jr. (1993), Cloud Dynamics, 573 pp., Elsevier, New York.

Helten, M., H. G. J. Smit, W. Sträter, D. Kley, M. Zöger, R. Busen, and P. Nedelec (1998), Calibration and performance of automatic compact instrumentation for the measurement of relative humidity from passenger aircraft, J. Geophys. Res., 103, 25,643-25,652.

Helten, M., H. G. J. Smit, D. Kley, J. Ovarlez, H. Schlager, R. Baumann, U. Schumann, P. Nedelec, and A. Marenco (1999), In-flight intercomparison of MOZAIC and POLINAT water vapor measurements, J. Geophys. Res., 104, 26,087-26,096.

Jensen, M. P., and A. D. Del Genio (2006), Factors limiting convective cloud-top height at the ARM Nauru Island climate research facility, J. Clim., 19, 2105-2117.

Johnson, J. E., R. H. Gammon, J. Larsen, T. S. Bates, S. J. Oltmans, and J. C. Farmer (1990), Ozone in the marine boundary layer over the Pacific and Indian Oceans: Latitudinal gradients and diurnal cycles, J. Geophys. Res., 95, 11,847-11,856.

Johnson, R. H., P. E. Ciesielski, and K. A. Hart (1996), Tropical inversions near the $0^{\circ} \mathrm{C}$ level, J. Atmos. Sci., 53, $1838-1855$.

Johnson, R. H., T. M. Rickenbach, S. A. Rutledge, P. E. Ciesielski, and W. H. Schubert (1999), Trimodal characteristics of tropical convection, J. Clim., 12, 2397-2418.

Kley, D., P. J. Crutzen, H. G. J. Smit, H. Vömel, S. J. Oltmans, H. Grassl, and V. Ramanathan (1996), Observations of near-zero ozone levels over the convective Pacific: Effects on air chemistry, Science, 274, 230-233.

Kley, D., H. G. J. Smit, H. Vömel, H. Grassl, V. Ramanathan, P. J. Crutzen, S. Williams, J. Meywerk, and S. J. Oltmans (1997), Tropospheric water vapour and ozone cross sections in a zonal plane over the central equatorial Pacific, Q. J. R. Meteorol. Soc., 123, 2009-2040.

Lelieveld, J., J. van Ardenne, H. Fischer, M. de Reus, J. Williams, and P. Winkler (2004), Increasing ozone over the Atlantic ocean, Science, $304,1483-1487$.

Luo, Z., D. Kley, R. H. Johnson, and H. G. Smit (2007), Ten years of measurements of tropical upper-tropospheric water vapor by MOZAIC, part I: Climatology, variability, transport and relation to deep convection, J. Clim., 20, 418-435.

Mapes, B. E., and P. Zuidema (1996), Radiative-dynamical consequences of dry tongues in the tropical troposphere, J. Atmos. Sci., 53, 620-638.

Marenco, A., et al. (1998), Measurement of ozone and water vapor by Airbus in-service aircraft: The MOZAIC airborne program, An overview, J. Geophy. Res., 103, 25,631-25,642.

Newell, R. E., Jr., K. K. Kelly, and S. C. Liu (1996), Vertical fine-scale atmospheric structure measured from NASA DC-8 during PEM-West A, J. Geophys. Res., 101(D1), 1943-1960.

Numaguti, A. R., K. Oki, K. Nakamura, K. Tsuboki, N. Misawa, T. Asai, and Y.-M. Kodma (1995), 4-5-day-period variation and low level dry air observed in the equatorial western Pacific during TOGA COARE, J. Meteorol. Soc. Jpn., 73, 267-290.

Parsons, D. B., K. Yoneyama, and J.-L. Redelsperger (2000), The evolution of the tropical western Pacific atmosphere-ocean system following the arrival of a dry intrusion, Q. J. R. Meteorol. Soc., 126, 517-548.

Piotrowicz, S. R., H. F. Bezdek, G. R. Harvey, and M. Springer-Young (1991), On the ozone minimum over the equatorial Pacific Ocean, J. Geophys. Res., 96, 18,679-18,687.

Redelsperger, J.-L., D. B. Parsons, and F. Guichard (2002), Recovery processes and factors limiting cloud-top height following the arrival of a dry intrusion observed during TOGA COARE, J. Atmos. Sci., 59, 2438-2457.

Reuter, G. W. (1986), A historical review of cumulus entrainment studies, Bull. Am. Meteorol. Soc., 67, 151-154.

Riehl, H., and J. S. Malkus (1958), On the heat balance in the equatorial trough zone, Geophysica, 6, 503-538.

Simon, P. (2000), Ozone/potential vorticity correlations, MOZAIC-II Technical Final Report [1996-1999], 74-77 pp., Lab. de Aeronom., Univ. Paul Sabatier, Toulouse, France. (Available at http://mozaic.aero.obs$\mathrm{mip} . \mathrm{fr} / \mathrm{web} /$ features/documents/report.html)

Smit, H. G. J. (2004), Tropospheric ozone as a tracer to investigate deep convection and its influence on the humidity in the marine tropics, $\mathrm{Ph} . \mathrm{D}$. thesis, Univ. Wuppertal, Wuppertal, Germany.

Smit, H. G. J., S. Gilge, and D. Kley (1990), The meridional distribution of ozone and water vapor over the Atlantic Ocean between $30^{\circ} \mathrm{S}$ and $52^{\circ} \mathrm{N}$ in September/October 1988, in Physico-Chemical Behaviour of Atmospheric Pollutants, edited by G. Restelli and G. Angeletti, CEC Air Pollution Report 23, Springer, New York.

Smit, H. G. J., et al. (2007), Assessment of the performance of ECC-ozonesondes under quasi-flight conditions in the environmental simulation chamber: Insights from the Juelich Ozone Sonde Intercomparison Experiment (JOSIE), J. Geophys. Res., 112, D19306, doi:10.1029/ 2006JD007308.

Thompson, A. M., B. G. Doddridge, J. C. White, R. D. Hudson, W. T. Luke, J. E. Johnston, B. J. Johnson, S. J. Oltmans, and R. Weller (2000), A tropical Atlantic paradox: Shipboard and satellite views of a tropospheric ozone maximum and wave-one in January-February 1999, Geophys. Res. Lett., 27, 3317-3320.

Thouret, V., A. Marenco, P. Nedelec, and C. Hrouhel (1998), Ozone climatologies at $9-12 \mathrm{~km}$ altitude as seen by the MOZAIC airborne program between September 1994 and August 1996, J. Geophys. Res., 103, $25,653-25,679$.

Weller, R., R. Lilischkis, O. Schrems, R. Neuber, and S. Wessel (1996), Vertical ozone distribution in the marine atmosphere over the central Atlantic Ocean $\left(56^{\circ} \mathrm{S}-50^{\circ} \mathrm{N}\right), J$. Geophys. Res., 101, 1387-1399.

Yanai, M., S. Esbensen, and J.-H. Chu (1973), Determination of bulk properties of tropical cloud clusters from large-scale heat and moisture budgets, J. Atmos. Sci., 30, 611-627.

Zipser, E. J. (2003), Some views on "hot towers" after 50 years of tropical field programs and two years of TRMM data, Meteorol. Monogr., 29(51), $50-59$.

R. H. Johnson, D. Kley, and Z. Luo, Department of Atmospheric Science, Colorado State University, Fort Collins, CO 80523, USA. (d.kley@fzjuelich.de)

S. Nawrath, Potsdam Institute for Climate Impact Research, D-14473 Potsdam, Germany.

P. Nedelec, Laboratoire d'Aérologie, CNRS UMR5560, Observatoire Midi-Pyrénées, F-31400 Toulouse, France.

H. G. J. Smit, Institut für Chemie und Dynamik der Geosphäre (ICG-II), Forschungszentrum Jülich, D-52425 Jülich, Germany. 